TEME, г. XLV, бр. 1, јануар - март 2021, стр. 1-17

\begin{tabular}{lr}
\hline \hline Прегледни рад & https://doi.org/10.22190/TEME180601001T \\
Примљено: 1. 6. 2018 & UDK 371.12:37:017
\end{tabular}

Ревидирана верзија: 22. 1. 2021.

Одобрено за штампу: 26. 2. 2021.

\title{
ПРИПРЕМА БУДУЋИХ УЧИТЕЉА И ПРОБЛЕМ ФОРМИРАҢА КУЛТУРНОГ ИДЕНТИТЕТА
}

\author{
Весна С. Трифуновић ${ }^{1 *}$, Данијела Здравковић², \\ Драгана Станојевић ${ }^{2}$
}

${ }^{1}$ Универзитет у Крагујевцу, Факултет педагошких наука, Јагодина, Србија ${ }^{2}$ Универзитет у Нишу, Педагошки факултет, Врање, Србија

\begin{abstract}
Апстракт
У Републици Србији се од 2000. године спроводе реформе образовања са циљем хармонизације овог важног подручја друштва са тзв. европским образовним простором. Читав низ измена које су законски усвојене и у пракси се спроводе на свим нивоима институционализованог образовања су, углавном, усмерене ка стандардизацији и унификацији „националног” образовања са образовним парадигмама неолибералног друштва. Одржавање континуитета развоја културе и формирање културног идентитета су важна питања за укупни друштвени развој, а њима се у стратегији образовања не поклања одговарајућа пажња, као што је и институционална припрема будућих учитеља недовољно усредсређена на ову проблематику.

У овом раду се разматрају: 1) нормативни оквир који уређује подручје основног образовања и формирање културног идентитета у Републици Србији, 2) чиниоци који утичу на процес обучавања будућих учитеља за формирање културног идентитета и 3) компетенције учитеља као подршка формирању културног идентитета деце млађег школског узраста.

Истиче се значај усаглашености основних смерница нормативног оквира који уређује основно образовање и формирање културног идентитета са основним интенцијама припреме будућих учитеља - нарочито са аспекта улоге учитеља у процесу утемељења и очувања културног идентитета генерација пристиглих за обухват обавезним основним образовањем у контексту међугенерацијског преношења културе, културних образаца и вредности. Истиче се, притом недовољна, присутност садржаја у обучавању будућих учитеља који би их на одговарајући начин припремили за разумевање сложеног проблема формирања културног идентитета.

Аутори истичу важност утемељености припреме будућих учитеља на академским знањима о друштву, историји и култури. Рад има за циљ да истакне значај развијања компетенција учитеља неопходних за разумевање проблема идентитета и конституисање културног идентитета.

У раду ће бити коришћена дескриптивно-аналитичка метода.

Кључне речи: припрема будућих учитеља, културни идентитет, вредности, студијски програми, компетенције учитеља.
\end{abstract}

\footnotetext{
* Аутор за кореспонденцију: Весна С. Трифуновић, Универзитет у Крагујевцу, Факултет педагошких наука, Милана Мијалковића 14, 35000 Јагодина, Србија, dimitrije95@ptt.rs
} 
В. С. Трифуновић, Д. Здравковић, Д. Станојевић

\title{
THE EDUCATION OF FUTURE TEACHERS AND THE PROBLEM OF THE FORMATION OF A CULTURAL IDENTITY
}

\begin{abstract}
In the Republic of Serbia, education reforms have been implemented since 2000 with the aim of harmonizing this important field of society with the so-called European Education Area. The whole range of changes lawfully adopted and applied in practice at all levels of institutionalized education is mainly directed towards the standardization and unification of "domestic" education with the educational paradigms of a neoliberal society. Maintaining the continuity of cultural development and the formation of cultural identity are important issues for overall social development, and they are not given proper attention in the education strategy. In addition to that, the institutional preparation of future teachers does not sufficiently focus on this issue.

In this paper we consider: (1) the normative framework that regulates the field of primary education and the formation of cultural identity in the Republic of Serbia, (2) the factors influencing the process of training future teachers for the formation of cultural identity and (3) the teachers' competencies as a support to the formation of the cultural identity of younger school-age children.

The importance of the harmonization of the basic guidelines of the normative framework regulating primary education and the formation of cultural identity with the basic intentions of preparing future teachers is emphasized. Especially from the perspective of the role of teachers in the process of establishing and preserving the cultural identity of generations reaching compulsory primary education in the context of intergenerational transmission of culture, cultural patterns and values. At the same time, the paper emphasizes the insufficient presence of content in the education of future teachers that would adequately prepare them for understanding the complex problem of forming a cultural identity.

The authors point out the importance of the groundedness of future teachers' preparation in terms of their academic knowledge of society, history and culture. The aim of the paper is to emphasize the importance of developing teachers' competencies necessary for understanding identity issues and forming a cultural identity.

The paper employs the descriptive-analytical method.
\end{abstract}

Key words: preparation of future teachers, cultural identity, values, study programs, teachers' competencies.

\section{УВОД}

У разматрању проблематике припреме будућих учитеља за активно учешће у стварању основа за формирање културног идентитета нових генерација пристиглих за обухват основним образовањем, пошло се од схватања да институције друштва, нарочито школа, активно учествују у преношењу културе: 1) према Емилу Диркему (Emile Durkheim), битна улога образовног система је преношење културе друштва као целине (Диркем, 1981); 2) према Пјеру Бурдиjey (Pierre Bourdieu), образовни систем репродукује културу владајућих група, дефинисану као културу достојну тежње и поседовања (Bourdieu, 1973); 3) Џон Г. Огбу (John G. Ogbu) сматра да је основна 
улога образовног система његова трансмисиона улога - преношење доминантне културе учесницима образовања (Ogbu, 1989); 4) према Зорану Аврамовићу, питање преношења доминантне културе компликује се у друштвима која су поликултурна јер се поставља питање праве размере између културолошких садржаја већине и мањина које чине дато друштво и начина њиховог преношења кроз школске програме (Аврамовић, 2003).

Школе су, по свему судећи, важан извор формирања културе: остварују снажан утицај на индивидуу, „уводе је у културу” и омогућују да „постане пуноправни члан друштва” (Кон, 1991, p. 183). Посебно се издваја улога учитеља за децу млађег школског узраста (деца узраста од 7 до 11 година). Учитељи могу да, преносећи или потискујући одређене вредности и обрасце културе, утичу на могућност формирања културног идентитета школске деце. Да ли ће и на који начин учитељ остварити ту могућност у великој мери је повезано са његовом припремом - знањем и вештинама којима је овладао и ставовима које је формирао кроз институционализовано образовање.

Припрема будућих учитеља одређена је друштвеним циљевима образовања и основном идејом о социјалној и културној организацији живота коју заступају владајуће групације. Учитељ је, дакле, у свом деловању, које укључује и деловање у процесу стварања основа за формирање културног идентитета школске деце, ограничен ширим друштвеним интересима и потребама, које могу бити подстицај или препрека утемељењу и развијању колективних идентитета.

У савременом добу се појму образовања придају значења донекле различита од уобичајеног поимања као „структуриране трансмисије знања унутар формалне институције" (Giddens i Birdsall, 2007, p. 523). Образовање се данас не одвија само у институционалним оквирима, а његова основна улога није само припремање појединаца за остваривање радних улога у складу са достигнутом поделом рада у датом друштву, већ представља и припрему за смислени живот: образовање „спрема људе за запослење и, још битније, за вођење смислених живота" (Nusbaum, 2012, p. 19). Остваривање ове припреме повезано је са разумевањем суштинских циљева образовања у култури датог друштва. Повезаност између образовања и култуpe, као референтног оквира у коме се одвија, претпоставља разоткривање читавог низа сложених међуутицаја, у чему култура има одређујући утицај на подручје образовања. Култура и социјална организација унутар које се развија структурирају подручје образовања утврђују друштвену улогу и циљеве образовања, вредности које ће преносити, моделе понашања које ће обликовати. Сви наведени аспекти деловања су нормирани и представљени датим политикама образовања, укључујући и „политику” културне репродукције и ра- 
споделе културног капитала међу припадницима различитих социокултурних групација у друштву.

Опстанак културе подразумева њено непрестано преношење и богаћење управо кроз образовање, ,а сврха организованог образовања је постизање овог циља" (UNESCO, 2006: 13). Образовање, дакле, посредује култури. Језик, обичаји, традиција, религија као конститутивни елементи културе (Божиловић, 2010) добијају посебну улогу у процесу формирања културног идентитета. Културни идентитет је облик колективног идентитета, али и, према Загорки Голубовић (1999), објективна основа самоидентитета која остварује одлучујући утицај на појединца. Успостављени колективни идентитет у значајној мери утиче на појединца и формирање његовог осећаја припадања групи, тј. утиче на „веровања, вредности и опредељености, а у неким случајевима и одговарајуће понашање и склоности” (Гевирц и Криб, 2012, р. 233). Грађење идентитета је процес који подразумева активитет појединца и његову спремност да стално промишља о себи и другима. Међутим, не подразумева прихватање једном добијених одговора на кључна питања као једино могуће одговоре. Грађење идентитета је процес, а не једнократни чин који успоставља једнозначни реалитет. Непрестано промишљање света и себе самог појединца води „ка питањима о властитом месту и односима према тим световима и сталном довођењу у питање властитог идентитета" (Стојковић, 2008, р. 39), као и опредељењу за његову одбрану или редефинисање.

Полазиште за дефинисање културног идентитета према Бранимиру Стојковићу (2008) могу бити следећи елементи: „а) истовремено везивање идентитета за појединца и групу, б) схватање идентитета као односа (релације) према другоме, односно према другима, в) историјска природа (променљивост) идентитета, г) релативност идентитета у односу на контекст (друге идентитете)". На основу назначених елемената, исти аутор дефинише културни идентитет као „самосвест припадника једне групе која историјски настаје и развија се у зависности од критеријума које та група успоставља у односима са припадницима других група" (Стојковић, 2008, р. 26). Елементи попут односа према другоме, променљивост, контекстуалности, повезаности и са појединщем и са групом указују на вишедимензионалност и сложеност овог појма. Културни идентитет припадници једног друштва граде на свести о поседовању заједничких културних карактеристика и деле вредносне садржаје који конституишу културу, и то традицију, језик, религију, право, обичаје, фолклор, митологију, уметност (УНЕСКО, 1982). Појединци и групе формирају културни идентитет путем социјалног учења (Коковић, 2009), тј. формирају вредносни референтни оквир који подразумева рефлексивно су- 
очавање са сопственом културом и њено реинтерпретирање (Голубовић, 1999).

Неопходно је да институционализовано образовање у домену формирања културног идентитета оствари два задатка: а) преноси знаға о различитим елементима културног идентитета (језик, традиција, историја, уметност и др.) и б) омогући да се пренето знање доживи као властито. Уколико је основна намера друштва очување континуитета културног развоја, онда постаје важно која се знања и вредности преносе образовањем (Ogbu, 1989; Гевирц и Криб, 2012) и да ли пренета знања представљају основу за формирање културног идентитета самих учесника образовања.

\section{МЕТОД}

Предмет овог рада је истраживање основних смерница нормативног оквира који уређује основно образовање у равни формирања културног идентитета и усаглашеност припреме будућих учитеља са аспекта њихове улоге у процесу формирања културног идентитета деце млађег школског узраста.

Циљ је да се испита: а) да ли законски документи који уређују први циклус основног образовања и васпитања омогућавају остваривање општих циљева и исхода образовања који се односе на неговање културног идентитета, уважавање и поштовање културних различитости; б) да ли институционализована припрема будућих учитеља пружа адекватна знања о друштву, историји и култури, важна за разумевање идентитарног феномена и формирање културног идентитета.

У складу са предметом и циљевима рада, постављени су следећи задаци:

1) анализирати нормативни оквир који уређује подручје основног образовања са аспекта формирања културног идентитета;

2) анализирати образовање учитеља са аспекта стицања компетенција за формирање културног идентитета деце млађег школског узраста.

Формулисана је следећа општа хипотеза:

Са аспекта формирања културног идентитета у Републици Сpбији, нормативни оквир који уређује подручје основног образовања пружа могућност развијања осећаја припадности ученика одређеној културној заједници, прихватања за њу карактеристичних вредности и разумевања различитих културних идентитета. Међутим, припрема будућих учитеља није усаглашена са поменутим намерама.

Формулисане су и следеће посебне хипотезе:

1) Студијски програми за учитеље не нуде у довољној мери садржаје који су у функцији разумевања друштва у коме живе и света у целини - недостају садржаји у којима је на конзистентан начин 
представљена економска, социјална, политичка и културна проблематика.

2) Студијски програми за учитеље не нуде у довољној мери садржаје који представљају основу за формирање културног идентитета.

Методе коришћене у овом раду су: анализа секундарне грађе (међународних докумената и домаћег „кровног” закона о основном образовању, студијски програми Факултета педагошких наука у Јагодини), грађе која уређује однос образовање - културни идентиmem, дескриптивни метод. Коришћена је и анализа случаја.

У области друштвених наука анализа случаја је врста квалитативне анализе. У социологији се употребљава више сличних израза: студија случаја (енгл. case analysis) и метод случаја (енгл. case method).

Анализа случаја није заправо нека специфична техника, него начин организовања социјалних података, с циљем да се сачува јединствени карактер објекта који се проучава (Гуд и Хет, 1996, р. 12). Пошто се оријентише на проучавање целине случаја, тај приступ се означава као холистички. Притом „случај” може бити све - од појединца, па до глобалног друштва. Анализом случаја постиже се интензитет и дубина у социолошким истраживањима. Ипак, један од највећих недостатака ове методе налази се у чињеници да се тешко обезбеђује квалитативна стандардизација у прикупљању и анализи података. То је вероватно разлог што су се најчешће приговори критичара анализе случаја односили на пристрасност истраживача и на непоузданост прикупљених података (Суботић, 2011, стр. 425). И поред наведених опасности, аутори су се определили за наведену анализу будући да она пружа могућност за формулисање плодних хипотеза за даље истраживање дате проблематике.

\section{НОРМАТИВНИ ОКВИР ОСНОВНОГ ОБРАЗОВАҢА СА АСПЕКТА ФОРМИРАЬА КУЛТУРНОГ ИДЕНТИТЕТА}

Повезаност између друштва и образовања може се пратити у равни исказивања друштвених интереса кроз приоритете образовних политика, и то на нивоу одређивања циљева образовања, циљева предмета на различитим нивоима образовања и компетенција учесника одређених образовних циклуса. У различитим земљама приоритети образовања се разликују: анализа ОЕЦД-а (Organization for Economic Cooperation and Development) показује да у дефинисању кључних компетенција актери из различитих подручја друштва (економије, образовања, политике, културе, науке, уметности) нису сагласни - најмање сагласности било је за компетенције повезане са културним идентитетом (Trier, 2001). 
Српско друштво тежи интеграцији са Европском унијом (ЕУ), а образовање, које се испољава као инструмент интеграције, усаглашава се са тзв. европским образовним простором. У земљама чланицама ЕУ кључне компетенције за целоживотно учење (Recommendation of the European Parliament and of the Council on key competences for lifelong learning, 2006) укључују и компетенцију културна свест и израз, коjа се непосредно тиче културног идентитета.

Глобализацијски процеси намећу стандардизацију у готово свим подручјима различитих друштава, а подручје образовања је нарочито изложено овим утицајима, чији је крајњи ефекат његова хомогенизација: националне образовне политике прихватају наднационалне смернице и препоруке које уређују подручје образовања (Барлоу и Робертсон, 2003).

Читав низ препорука различитих међународних организација има снажан утицај на избор и начин преношења знања која представљају основу за уређење подручја образовања и формирање културног идентитета у Републици Србији: 1) Универзална декларација о културној разноликости (Организација за образовање, науку и културу Уједињених нација - УНЕСКО, 2001); 2) Смернице за интеркултурално образовање (УНЕСКО, 2006); 3) Бела књига о интеркултуралном дијалогу (Savet Evrope, 2008); 4) Препорука о интеркултуралном дијалогу и слици о другоме у настави историје (Савет Европе, 2011); 4) Повеље о образовању за демократско грађанство и људска права Савета Европе (2010); 5) Препорука Скупштине Савеmа Европе о религији и демократији (1999); 6) Препорука савета Европе Образовање и религија (2005); 7) Препорука о матерњем језику у школском образовању (Савет Европе, 2006); 8) Препорука о унапређењу наставе европске књижевности (Савет Европе, 2008); 9) Приручник са смерницама о припреми планова и програма за наставу о религијама и веровањима: Toledo guiding principles on teaching about religions and beliefs in public schools (Организација за европску сарадњу и безбедност - ОЕБС, 2007); 10) Европска агенда за култуpy (Резолуција Савета Европске уније, 2007).

Заједнички именитељ наведених докумената је мултикултурални концепт који се заснива на универзалним вредностима, на поштовању културних разлика и уважавању различитих културних идентитета (Трифуновић, 2012). У складу са наведеним међународним документима, у Републици Србији су донети закони о основном образовању и основној школи који су, између осталог, имали за циљ сензитивизацију образовања за питања културног идентитета: Закон о основама система образовања и васпитања, 2009; Закон о основном образовағу и васпитаюу 2013, 2017. и други.

Циљеви образовања и васпитања у члану 4 закона из 2009. године су да појединац стекне знања, развије способности и формира 
ставове који ће му, сматра се, омогућити да кроз најразноврсније интеракције у друштву оствари пун развој личности. Већина циљева индиректно је повезана са вредностима културе, у најширем смислу, а у тачкама 13, 14 и 15 наведене су вредности повезане са културним идентитетом које се кроз образовање преносе и развијају, и то: а) „развијање способности за улогу одговорног грађанина, за живот у демократски уређеном и хуманом друштву заснованом на поштовању људских и грађанских права, права на различитост и бризи за друге...” (тачка 13); б) „формирање ставова, уверења и система вредности, развој личног и националног идентитета, развијање свести и осећања припадности држави Србији, поштовање и неговање српског језика и свог језика, традиције и културе српског народа, националних мањина и етничких заједница, других народа, развијање мултикултурализма, поштовање и очување националне и светске културне баштине” (тачка 14); в) „развој и поштовање расне, националне, културне, језичке, верске, родне, полне и узрасне равноправности, толеранције и уважавање различитости" (тачка 15). Идентично формулисани циљеви налазе се и у Закону о основном образовању и васпитању донетом 2013. године.

У Закону о основном образовағу и васпитағу донетом 2017. године, циљеви основног образовања и васпитања у члану 21 , ставови 15 и 16 тичу се проблематике културног идентитета. Циљеви основног образовања су, поред других, и „развој и поштовање расне, националне, културне, језичке, верске, родне, полне и узрасне равноправности, толеранције и уважавање различитости" (став 15), као и „развијање личног и националног идентитета, развијање свести и осећања припадности Републици Србији, поштовање и неговање српског језика и матерњег језика, традиције и културе српског народа и националних мањина, развијање интеркултуралности, поштовање и очување националне и светске културне баштине" (став 16).

У документу названом Стратегија образовања у Републици Србији до 2020. године (у даљем тексту Стратегија) одређују се правци развоја образовања у домену културе и културног идентитета. Стратегија истиче потребу „...да се истрајно и посвећено чува и негује национално културно наслеђе и идентитет, развија толерантан и кооперативан однос према другим културама и јача допринос културе укупном квалитету живота становника Републике Србије" (стр. 5). Истакнуто је да је темељ целокупног система образовања и васпитања основно образовање и васпитање, чија је једна од функција и да развија „ставове и вредности неопходне за формирање националног и културног идентитета...” (стр. 28).

Стратегија наглашава опредељење за формирање, развој и очување културног идентитета заснованог на сопственом културном наслеђу и опредељење за поштовање и разумевање културних специ- 
фичности и разлика које из њих проистичу на локалном и глобалном нивоу.

Исходи основног образовања и васпитања конкретизују очекиване резултате овог нивоа: у члану 22 Закона о основном образовању u васпитању (2013) наведени су исходи у 14 тачака, међу којима су и исходи повезани са формирањем културног идентитета. Претпоставља се да ће ученици који су завршили основно образовање усвојити вредности културног идентитета заснованог на сопственом културном наслеђу и универзалним вредностима, и то: а) „имати развијено осећање припадности сопственој породици, нацији и култури, познавати сопствену традицију и доприносити њеном очувању и развоју” (Закон, 2013, члан 22, тачка 12); б) ,знати и поштовати традицију, идентитет и културу других заједница и бити способни да сарађују са њиховим припадницима" (Закон, 2013, члан 22, тачка 13); в) ,умети да препознају и уваже људска и дечја права и бити способни да активно учествују у њиховом остваривању” (Закон 2013, члан 22, тачка 11$)$.

У Закону о основном образовању и васпитању (2017) наведени су исходи основног образовања и васпитања у члану 22 , међу којима су и исходи повезани са стварањем основе за формирање културног идентитета (став 12 и 13). У ставу 12 се истиче да ће ученици „имати развијено осећање припадности сопственој породици, нацији и култури, познавати сопствену традицију и доприносити њеном очувању и развоју”, док се у ставу 13 наглашава да ће ученици „знати и поштовати традицију, идентитет и културу других заједница и бити способни да сарађују са њиховим припадницима" (Закон, 2017, члан 22 , став 12 и 13$)$.

\section{ОБРАЗОВАЬЕ БУДУЋИХ УЧИТЕЉА И ФОРМИРАЊЕ КУЛТУРНОГ ИДЕНТИТЕТА}

Свакој етапи у развоју друштва „одговара” и одређена представа о појединцу, која се уобличава у његовом сусрету са различитим друштвеним механизмима, укључујући и институционализовано образовање. Нова парадигма образовања учитеља истиче потребу професионализације овог занимања, која се заснива на стицању систематски заокруженог теоријског знања о образовању, које укључује филозофску, социолошку, педагошку, психолошку, антрополошку, културолошку димензију образовања. Неопходно је да студијски програми за припрему учитеља, почев од академских основних студија, преко мастер и докторских студија, буду у функцији остваривања циљева и достизања исхода предвиђених Законом о основном образовању и васпитању. Један од тих циљева тиче се и припреме учитеља за стварање основе за формирање културног идентитета 
ученика млађег школског узраста, што подразумева и њихово овладавање знањима из социологије, културе и историје. У том контексту, творци образовних политика морали би да постигну консензус о групи обавезних предмета који „долазе” из наведених научних дисциплина, а који би постали интегрални део студијских програма за учитеље. Висок академски ниво базичног образовања учитеља ствара претпоставке за њихов квалитетнији професионални развој. Друштво данас очекује од учитеља да, у складу са порастом комплексности њихове улоге у васпитнообразовном процесу, поседују бројне професионалне компетенције (инструменталне, интерперсоналне, системске). Пресудну улогу у формирању професионалних компетенција учитеља имају студијски програми на високошколским институцијама које обучавају учитеље.

Реформа образовања у равни студијских програма за образовање учитеља, која траје скоро две деценије, у првом реду тежи усклађивању са европским образовним стандардима. У пракси је то означило увођење „тростепеног студирања” (основне, мастер и докторске студије) и редизајнирање студијских програма, чији је заједнички именитељ редуковање тзв. обавезних предмета из друштвенохуманистичког поља, нарочито из научних области Социологије, Историје и Науке о култури, који представљају темељ за разумевање идентитарног феномена и важности формирања културног идентитета у условима растућег глобализма. Аутономија факултета у осмишљавању студијских програма довела је до различитих схватања о „степену важности” друштвених наука и општеобразовних предмета који их представљају, нарочито од 2006. године. На примеру Факултета педагошких наука у Јагодини, могу се уочити следећи процеси након прихватања тзв. Болоњског режима студирања (2006): 1) редуковање предмета из научне области Социологије - (а) из студијског програма основних академских студија Учитељ искључени су предмети Општа социологија, Социологија породице и детињства и Савремено друштво и демократија, предмет у оквиру модула Грађанско васпитање, као и са̂м модул; 2) елиминисање садржаја из историје искључивањем предмета Интердисциплинарни семинар на смеру Учитељ, чији су интегрални део били и садржаји из историје; 3) фрагментизаиија предмета - свођење смислене целине једног подручја проучавања на парцијална питања (фрагменте) који добијају статус предмета, што онемогућује студенте да сагледају и разумеју све димензије дате проблематике (Књига предмета, 2014). Генерације учитеља су, дакле, већ одшколоване, а да нису имале додир са опитом социологијом, историјом и систематизованим садржајима који би их упознали са развојем властите културе и културе уопште.

Теоријски, важну улогу у образовању будућих учитеља имају тзв. предмети из корпуса друштвених наука, посебно из социолошке 
научне области, и то следећи предмети: Социологија или Увод у науку о друштву, Социологија породице, Социологија детињства, Социологија културе.

Противљење социолошком образовању будућих наставника долази од стране оних који не располажу потребним знањима из социолошких наука, али и уколико располажу тим знањима, по природи су конзервативни. У сваком случају, противљење овом образовању тежи свођењу наставника на методичке практичаре, прагматичне репродуктивце и оспорава њихово формирање као широко образовних интелектуалаца који треба да остваре нов квалитет основног образовања (...) у „учећој цивилизацији” двадесет и првог века (Марковић, 2005, стр. 88).

Речју, у овом раду упоришна тачка није омеђена једино устаљеном вишегодишњом праксом о значају и важности социолошког образовања наставника у основном образовању, већ се истиче потреба и валоризација научног проучавања образовања као друштвене појаве у оквиру структуре студијског програма на смеру Учитељ. Очигледно је да се у структури поменутог студијског програма налази само један предмет из уже научне области Социологија као обавезни општеобразовни, и то Социологија образовања (на првој години студија). У оквиру изборног предметног подручја основних академских студија (ОАС) Учитељ у оквиру предмета изборног блока 1 (прва година студија) студентима се даје могућност да, између других, бирају предмет Породица и савремено друштво. Такође, на другој години студија изборно предметно подручје ОАС Учитељ у оквиру предмета изборног блока 3 студентима омогућује да, између других, бирају предмет Култура младих (Табеларни приказ студијског програма, 2018).

Редукција теоријских знања о друштву и култури, као и непостојање садржаја из историје, ускраћује студентима, будућим учитељима, ону врсту знања која им омогућује да остваре улогу припремања деце млађег школског узраста за живот у друштву, што је, иначе, једна од препорука Међународне комисије за развој образовања у 21. веку (Делор, 1996). Усвајањем одређеног корпуса знања о друштву, култури и историји будући учитељи били би припремљени да препознају елементе важне за формирање културног идентитета школске деце, правећи разлику између оних који су на добробит појединца и опште добро и оних који су етноцентрични.

Знања добијена у институционализованом процесу образовања и професионалне компетенције које је учитељ развио, претпоставља се, омогућују учитељу да буде проактивни учесник у процесима социјализације и културализације деце млађег школског узраста. Учитељ, захваљујући иницијалном образовању, може да постане 
важан чинилац формирања идентитета школске деце: индивидуалног и колективних, а посебно културног идентитета.

Формирани културни идентитет одређује однос појединца према групи из које потиче и према различитим другим групама. Учитељ који је стекао широка општа знања о друштву, историји и култури може значајно да утиче: 1) на формирање свести школске деце о посебности групе којој припадају и разумевање различитости карактеристичних за друге појединце и групе; њихове способности да „ствари” посматрају из позиције другог и способности за емпатију и саосећање са другима; 2) на формирање свести школске деце о посебности групе којој припадају и успостављање односа према другима. Стога је неопходно да се у процесу образовања будућих учитеља развијају и компетенције за разумевање проблема идентитета и формирање културног идентитета. Њихово развијање, међутим, не може да се поистовети са усвајањем одређених садржаја у оквиру одређеног предмета датог студијског програма, већ пре представља дугорочан процес у току кога се кроз учење, практичан рад и истраживачке делатности усвајају знања, стичу вештине и развијају способности усмерене ка спознаји комплексне проблематике идентитета и, на крају, успешном стварању основа за формирање културног идентитета деце млађег школског узраста.

\section{ЗАКљУЧАК}

У разматрању проблематике образовања будућих учитеља и формирања културног идентитета, дошло се до следећих закључака:

1) У документима који уређују подручје основног образовања у Републици Србији очигледно је декларативно опредељење за мултикултурални концепт који се заснива како на очувању сопственог културног наслеђа тако и на универзалним вредностима; затим, на поштовању културних разлика и различитих културних идентитета. Национална регулатива је у овом домену у потпуности усклађена са препорукама различитих међународних докумената и представља израз хармонизације „домаћег” образовања са ширим образовним простором, пре свега европским.

2) На факултету који образује будуће учитеље од 2006. године долази до редукције теоријских знања о друштву и култури и до елиминисања садржаја из историје (који су били део предмета Интердисциплинарни практикум), што доводи до неадекватне припремљености дипломираних учитеља за активно учествовање у процесу формирања културног идентитета деце млађег школског узраста. Стога је неопходно редизајнирање студијског програма у циљу инкорпорирања ширих знања о друштву, култури и историји кроз одговарајуће обавезне студијске предмете. 
3) Развој професионалних компетенција учитеља је у непосредној вези са дефинисањем стандарда у образовању учитеља, као и питањем базичне припреме учитеља. Концепт образовања учитеља, међутим, није хармонизован на територији Републике Србије: разлике у „понуди" општеобразовних предмета, у броју обавезних предмета и понуди изборних предмета могу да буду повезане са припремљеношћу учитеља за стварања основе за формирање културног идентитета.

4) Постоји неусаглашеност нормативног оквира који уређује основно образовање са аспекта формирања културног идентитета и основних интенција институционализованог образовања будућих учитеља у димензији њихове припреме за вођење процеса утемељења и очувања културног идентитета генерација пристиглих за обухват обавезним основним образовањем.

\section{ЛИТЕРАТУРА}

Асман, А. (2012). Дуга сенка прошлости. [Long Shadow of the Past]. Београд: Clio.

Аврамовић, 3. (2003). Културни идентитет у образовању: неизбежност разлика [Cultural identity in education: the inevitability of differences]. У: С. Шевкушић (ур.) Уважавање различитости и образовање. [Respect for diversity and education], Београд: Институт за педагошка истраживања,143-149.

Барлоу, М. и Робертсон, Х-Џ. (2003). Хомогенизација школства [Homogenization of Education]. У Мандер Џ. и Голдсмит, Е. (ур.), Глобализаиија [Globalization], стр. 81-96. Београд: Clio.

Божиловић, Н. (2010). Традиција и модернизација - европске перспективе културе на Балкану. [Tradition and modernization - European perspectives of culture in the Balkans]. Социологија [Sociology], 52(2), 113-126.

Bourdieu, P. (1973). Cultural Reproduction and Social Reproduction. In Knowledge, Education and Cultural Change edited by R. Brown, pp. 71-112. London: Tavistock.

Council of Europe, Parliamentary Assembly.(2005). CoE Recommendation 1720 (2005) Education and religion Text adopted by the Assembly on 4 October 2005 (27th Sitting). https://assembly.coe.int/nw/xml/XRef/Xref-XML2HTML-en.asp?fileid= 17373\&lang=en (Приступљено:19. 7. 2019).

Делор, Ж. (1996). Образовағе скривена ризнииа [Education - hidden treasury]. Београд: Министарство просвете Републике Србије.

Диркем, Е. (1981). Васпитање и соииологија [Upbringing and Sociology]. Београд: Сазнање.

EU Commission. (2007). Key competences for lifelong learning. European Reference Framework .Luxembourg: Office for Official Publications of the European Communities http://www.alfa-trall.eu/wp-content/uploads/2012/01/EU2007keyCompetencesL3-brochure.pdf (Приступљено: 16. 6. 2015).

European Parliament. (2006). Recommendation of the European Parliament and of the Council of 18 December 2006 on Key Competences for Lifelong Learning (2006/962/EC) https://eurlex.europa.eu/LexUriServ/LexUriServ.do?uri=OJ:L: 2006:394:0010:0018:en:PDF (Приступљено: 19. 7. 2019). 
Гевирц, Ш. и Криб, А. (2012). Разумевање образовања (Социолоика перспектива) [Understanding of Education (Sociological perspective)]. Београд: Фабрика књига.

Giddens, A. i K. Birdsall. (2007). Sociologija [Sociology]. Zagreb: Globus.

Голубовић, 3. (1999). Jа и други. [Me and others]. Београд: Република.

Granese, A. (1978). Dijalektika odgoja [Dialectics and Upbringing]. Zagreb: Školska knjiga.

Гуд, В. и Хет, П. (1966). Методи соиијалног истраживања. [Social research methods]. Београд: Вук Караџић.

Књига предмета. (2014). Књига предмета (основне академске студије, Учитељ) [Course book (basic academic studies, Teacher]. Јагодина: Факултет педагошких наука. (https://pefja.kg.ac.rs/wpcontent/uploads/Knjiga\%20 predmeta/OASU.pdf (Приступљено: 19. 7. 2019)

Коковић, Д. (2009). Друштво и образовни капитал. [Society and educational capital]. Нови Сад: Mediterran Publishing.

Кон, И. С. (1991). Дете и култура [Child and Culture]. Београд: Завод за уџбенике и наставна средства.

Марковића, Д. Ж. (2005). Значај сочиолошког образовања наставника, [The importance of sociological teacher education], Међународни научни скуп „Савремени токови у образовању наставника”, Врање: Учитељски факултет у Врању, 85-88.

Нусбаум, М. (2012). Не за профит (Зашто је демократији потребна хуманистика?) [Not for profit (Why democracy needs humanism?)].Београд: Фабрика књига.

Ogbu, J. G. (1989). Pedagoška antropologija [Pedagogical anthropology]. Zagreb: Školske novine.

OSCE/ODIHR (2007). Toledo guiding principles on teaching about religions and beliefs in public schools https://www.osce.org/odihr/29154?download=true (Приступљено: 17. 4. 2018).

Savet Evrope (1999). Religion and democracy Recommendation 1396 http://assembly. coe.int/Main.asp?link=/Documents/AdoptedText/ta99/EREC1396.htm (Приступљено: 17. 6. 2015).

Savet Evrope (1999). Education and Religion. Recommendation 1720 http://www.assembly.coe.int/Main.asp?link=/Documents/AdoptedText/ta05/ERE C1720.htm (Приступљено: 17. 6. 2015).

Savet Evrope. (2006). The place of the mother tongue in school education (2006) http://www.assembly.coe.int/Main.asp?link=/Documents/AdoptedText/ta06/ER EC1740.htm (Приступљено: 16. 6. 2015).

Savet Evrope. (2008). Bela knjiga o interkulturalnom dijalogu Živimo zajedno jednaki u dostojanstvu. Strazbur http://www.coe.int///dg4/intercultural/Source/Pub_White_ Paper/WhitePaper_ID_SerbianVersion.pdf (Приступљено: 16. 6. 2015).

Savet Evrope. (2008). Promoting the teaching of European literature. http://assembly. coe.int/Main.asp?link=/Documents/AdoptedText/ta08/EREC1833.htm (Приступљено: 17. 6. 2015).

Savet Evrope (2010). Preporuka Komiteta ministara zemljama članicama u vezi sa Poveljom o obrazovanju za demokratsko građanstvo i ljudska prava Saveta Evrope.http://www.gradjanske.org/admin/article/download/files/Preporuka\%20 Komitet\%20ministara\%20\%20Saveta\%20Evrope.doc?id=709 (Приступљено: 17. 6. 2015).

Savet Evrope. (2011). Preporuka Komiteta ministara državama članicama o interkulturalnom dijalogu i slici o drugom u istoriji http://www.coe.int/t/dg4/ education/historyteaching/Source/Results/AdoptedTexts/CM\%20Rec(2011)6_S erbian.pdf (Приступљено: 16. 6. 2015). 
Стојковић, Б. (2008). Европски културни идентитет. Београд: Службени гласник. Стратегија развоја образовања у Србији до 2020. године [Strategy for the Development of Education in Serbia until 2020]. (2012). Београд: Влада Републике Србије, Министарство просвете, науке и технолошког развоја.

Суботић, Д. (2011). (Метод)олошки поступак студије случаја (case study) у друштвеним наукама. [Methodological case study procedure in social sciences]. Пословна економија, [Business Economics] 1/2011: 411-442.

Табеларни приказ студијског програма. (2018). Табеларни приказ, генерација уписана 2018/2019 [Tabular view, generation entered 2018/2019]. Јагодина: Факултет педагошких наука. https://pefja.kg.ac.rs/wpcontent/uploads/2019/ 02/Tabelarni_prikaz_OAS_U-_18_19.pdf (Приступљено: 19. 7. 2019).

Trier, U. (2001). 12 Countries Contributing to De Se Co A Summary Report. Neuchatel: Swiss http://www.deseco.admin.ch/bfs/deseco/en/index/05.parsys.1992.download List.41429.DownloadFile.tmp/sfsodesecoccpsummaryreport.pdf (Приступљено: 17. 6. 2015).

Трифуновић, В. (2012). Мултикултурализам и образовање: проблем плурализације идентитета [Multiculturalism and Education: the Problem of Pluralization of Identity]. Српска политичка мисао [Serbian political thought], 36/2: 75-92.

UNESCO. (1982). Mexico City Declaration on Cultural Policies, World Conference on Cultural Policies, Mexico City. https://culturalrights.net/descargas/drets_ culturals401.pdf (Приступљено: 19. 7. 2019).

UNESCO. (2001). Univerzalna deklaracija o kulturnoj raznolikosti [Universal Declaration on CulturalDiversity]http://www.unesco.org/new/fileadmin/ MULTIMEDIA/HQ/CLT/diversity/pdf/declaration_cultural_diversity_sr.pdf (Приступљено: 17. 6. 2015).

UNESCO. (2006). Guidelines on Intercultural Education.Paris(ED-2006/WS/59)CLD29366 http://unesdoc.unesco.org/images/0014/001478/147878e.pdf (Приступљено: 17. 6. 2015).

Закон о основама система образовања и васпитања [The Law on the Foundations of the Education System]. (2009). Београд: Службени гласник РС, 72/09, $52 / 11,55 / 13$.

Закон о основном образовању $и$ васпитању [Law on Primary Education and Upbringing]. (2013). Београд: Службени гласник РС, 55/13.

Закон о основном образовағу и васпитању [Law on Primary Education and Upbringing]. (2017). Београд: „Сл. гласник РС”, бр. 55/2013 і 101/2017). https://www.paragraf.rs/propisi/zakon_o_osnovnom_obrazovanju_i_vaspitanju. html (Приступљено: 16. 4. 2018). 


\title{
THE EDUCATION OF FUTURE TEACHERS AND THE PROBLEM OF THE FORMATION OF A CULTURAL IDENTITY
}

\author{
Vesna S.Trifunović ${ }^{1}$, Danijela Zdravković ${ }^{2}$, Dragana Stanojević ${ }^{2}$ \\ ${ }^{1}$ University of Kragujevac, Faculty of Education in Jagodina, Serbia \\ ${ }^{2}$ University of Niš, Faculty of Pedagogy in Vranje, Serbia
}

\begin{abstract}
Summary
Changes in learning organization are related to the social and cultural organization and in this light, it is beneficial to observe the education of future teachers in the Republic of Serbia since 2000. The demand for the harmonization of the Serbian society with the European Union (EU) standards is realized, first of all, through the harmonization of education with the so-called common European Education Area that is particularly sensitive to issues in the sphere of culture as culture plays a highly important role in the external relations of the European Union and its international cooperation. The European Agenda for Culture encourages the creation of a common cultural space that is perceived as crucial to the European integration process. Cultural specifics, multilingualism, values and heritage are respected in order to promote cultural diversity and the transversal role of culture. The educational reform in Serbia seeks to harmonize the normative framework regulating all levels of education, including elementary, with recommendations at the international level and within the European Union. The synergy of culture and education stands out as a strategic goal. In this light, the education of future teachers gains in importance, especially from the aspect of their preparation for creating the basis for the formation of the cultural identity of younger school-age children.

In addition to the normative framework, the creation of the basis for the formation of a cultural identity in institutionalized education implies the existing consensus on this issue between various important factors in society. Therefore, it is important to constantly review the strategic documents that regulate the field of education with the aim of including those determinants that will create the basis for the formation of the cultural identity of the participants in the educational process. The analysis of "domestic" documents regulating the field of primary education (Law on the Fundamentals of the Education System, 2009; Law on Primary Education and Upbringing, 2009, 2013, 2017) shows they are completely harmonized with the whole set of international documents concerning education and the relationship between culture and education. This confirms the general starting assumption: the normative framework regulating the field of primary education from the aspect of the formation of cultural identity in the Republic of Serbia provides the opportunity to develop the students' sense of belonging to a particular cultural community, the acceptance of its typical values and understanding of different cultural identities; however, the preparation of future teachers is not in line with these intentions.

On the other hand, the established tendencies in teacher education policy at teacher education and pedagogical faculties show, first, that the study programs reform has led to a reduction in subjects from the scientific fields of sociology, history and cultural sciences, which prevents the understanding of complex processes at the global level and in local communities. This confirms the first special hypothesis: study programs for teachers do not offer the sufficient amount of content in the function of understanding the society in which they live and societies world-wide - there is a lack of content in which the economic, social, political and cultural issue is consistently presented.
\end{abstract}


Secondly, the reduction in subjects from the scientific fields of sociology, history and cultural sciences prevents future teachers from responding to the challenge of creating the grounds for the formation of students' cultural identity. Teachers are not adequately prepared to achieve this important goal, which confirms the second special hypothesis: Study programs for teachers do not offer the sufficient amount of content that constitutes a basis for the formation of the cultural identity of younger school-age children. 